\title{
Epibiontic associations
}

\section{between apostomid ciliates Conidophrys spp. and amphipods associated with fish farms fouling in the western Mediterranean Sea}

\author{
Gregorio Fernandez-Leborans ${ }^{1 *}$, Victoria Fernandez-Gonzalez ${ }^{2}$, Pablo Sanchez-Jerez ${ }^{2}$ and Alvaro Roura ${ }^{3}$
}

\begin{abstract}
Fish farms commonly support high abundances of invertebrates, especially amphipods, associated with fouling communities developed over nets, ropes and buoys. Protozoan epibiont ciliates of the genus Conidophrys were observed on three of the most abundant amphipod species collected from ropes of a fish farm in the western Mediterranean Sea. The amphipod species were Ericthonius punctatus that presented the epibiont Conidophrys pitelkae, and Jassa marmorata and Jassa slatteryi with the epibiont C. pilisuctor. The epibionts were found in numbers fluctuating between 1 and 119 individuals in Jassa spp. (median value $=8$ ), higher than the number of epibionts found on $E$. punctatus that varied between 1 and 39 individuals (median value $=3$ ). The epibiosis on Jassa spp. also showed prevalence values (34.33\%) superior to those of E. punctatus (24\%). Differential distribution of the epibiont species on the surface of basibionts was detected: Conidophrys pilisuctor were more frequently found on the head and gnathopods of Jassa spp., while C. pitelkae were mainly counted on the head of E. punctatus. This is the first time that Conidoprhys were found on these amphipod species.
\end{abstract}

Keywords: Protozoa, Pilisuctorids, Marine habitats, Jassa spp., Ericthonius punctatus

\section{Background}

Epibiosis is a facultative association of two organisms: the epibiont and the basibiont. The term "epibiont" includes organisms that, during the sessile phase of their life cycle, are attached to the surface of a living substratum, while the basibiont lodges and constitutes support for the epibiont. Both concepts describe ecological functions $[38,41]$. The surface of the basibiont usually is colonised by the epibiont because the need of hard substrate. This is especially important in areas where hard substrata are scarce-such as pelagic habitats-and epibiont species with sessile phases of their life-cycle can attach to the surfaces available like the exoskeleton of crustacea. Basibiont species may belong to different animal phyla: Bryozoa, Chaetognata, Cnidaria, Crustacea,

\footnotetext{
*Correspondence: greg@bio.ucm.es

1 Department of Zoology, Complutense University, Madrid, Spain Full list of author information is available at the end of the article
}

Echinodermata, Enteropneusta, Insecta, Mollusca, Polychaeta, Porifera, Protozoa, Tunicata to Vertebrata [5, 35, 41]. Moreover, several crustacean groups also contain basibiont species: cladocerans, copepods, cirripedes, isopods, amphipods, and decapods [23]. The epibiont species on crustacea can belong to Porifera, Cnidaria, Platyhelminthes, Nemertea, Rotifera, Nematoda, as well as Polychaeta, Cirripedia, Decapoda, Gastropoda, Bivalvia, Phoronida, Bryozoa and Ascidiacea [20]. This association implies not only a protection and support for the epibiont, but also a great number of interactions (trophic, ecological, dispersive, etc.) and important effects on the partners of this relationship. In marine environments, epibiosis show a colonisation process that follows a series of consecutive phases, with a variety of organism groups involved. The area between epibiont and basibiont represent an interference mediation that can modify the effects not only on the organisms implicated, but also on the overall community [40]. The organisms had 
evolved showing alterations in physiology and morphology adapted to this relationship. The synchronization of life-cycles as in the case Zoothamnium intermedium and copepods [39], indicates the way in which epibiont and basibiont species evolved, producing mobile phases before the moult of the basibiont. The specificity of epibionts is also important, indeed, there are epibiont groups found exclusively on crustacea, such as protozoan chonotrichids, and epibiont species that only live in a certain crustacean species [26]. Among the ciliated protozoan epibionts on crustacea, one of the most specific groups is the apostomatid ciliates, including the order Pilisuctorida. The genus Conidophrys, belonging to this order, has been found on several crustacean species, mainly amphipods and isopods.

In the Mediterranean Sea, fish farms commonly support high abundances of invertebrates, especially amphipods, associated with fouling communities developed over nets, ropes and buoys. The cosmopolitan gammarids Ericthonius punctatus (Bate 1857), Jassa marmorata Holmes, 1905 and Jassa slatteryi Conlan, 1990 are frequently found in high abundances in these fouling habitats. Protozoan epibiont ciliates of the genus Conidophrys were observed on these three amphipod species collected from ropes of a fish farm in the western Mediterranean Sea. Accordingly, the aim of this work was to describe biological, biometric and taxonomical features of these epibionts in order to identify the Conidophrys species and to carry out a detailed study of their location on the body of Jassa spp. and E. punctatus to study whether the epibiont displays any preference for certain parts of the amphipods.

\section{Methods}

Amphipods, inhabiting fouling communities at a fish farm, were sampled by scraping fouling organisms from mooring ropes. The fish farm, dedicated to the on-growing of sea bream (Sparus aurata) and sea bass (Dicentrarchus labrax) were sampled off the coasts of Guardamar del Segura (Alicante, SE Spain: $38^{\circ} 5^{\prime} 45.88^{\prime \prime} \mathrm{N}$; $\left.0^{\circ} 36^{\prime} 15.84^{\prime \prime} \mathrm{W}\right)$ in June 2010 . The samples were sieved through a $250 \mu \mathrm{m}$ mesh with seawater and subsequently preserved in $4 \%$ formalin. Individuals of $J$. marmorata, Jassa slatteryi and E. punctatus were sorted out and identified and numbers per sample were recorded. A total of 200 individuals of Jassa spp. and 150 of E. punctatus were revised for the presence of epibionts and examinations were subdivided into different body parts: Head, first and second antennae, buccal parts, first and second gnathopods, pereiopods, pleopods, uropods, pereion, pleon, urosome and telson. The ciliates were identified using an Image Analysis (Zeiss K 300) system with a Zeiss compound microscope. The measurements of ciliates were done using the computer program ScopePhoto 2.0. For slide preparations, the material was stained with Boehmer's haematoxylin and mounted in Canada balsam. In order to identify the protozoan epibionts, they were isolated and treated using the silver carbonate technique, according to [21], and also with methyl green and neutral red.

For scanning electron microscopy, specimens of Jassa spp. were dehydrated in an ethanol series, critical pointdried in $\mathrm{CO}_{2}$ using a Polaron E3000, and sputter-coated in a Polaron SC500 using 60 \% gold-palladium. Samples were then examined with a Philips XC30.

SEM operating at $15 \mathrm{kV}$. For transmission electron microscopy, Jassa spp. pereiopods were fixed in $3.0 \%$ glutaraldehyde in $0.2 \mathrm{M}$ sodium cacodylate buffer, $\mathrm{pH}$ 7.2 for $12 \mathrm{~h}$ at $48 \mathrm{C}$, washed in the same buffer for $4 \mathrm{~h}$ at $48 \mathrm{C}$ and then postfixed in buffered $2.0 \%$ osmium tetroxide for $4 \mathrm{~h}$ at the same temperature. After dehydration in a graded ethanol series, the pereiopods were embedded in Epon and sectioned with a diamond knife to identify the regions where the ciliates were attached to the pereiopod. Once located, ultrathin sections were prepared, double-stained with uranyl acetate and lead citrate, and observed in a JEOL 100CXII TEM operated at $80 \mathrm{kV}$. Statistical analyses (multiple-sample comparison and correlation analyses) were performed using the Statgraphics program.

\section{Results}

\section{The epibiont species}

Two species were identify, Conidophrys pilisuctor Chatton \& Lwoff, 1934 and Conidophrys pitelkae Bradbury, 1975, following the next systematic classification:

Phylum Intramacronucleata Lynn, 1996

Class Oligohymenophorea De Puytorac et al., 1974

Subclass Apostomatia Chatton \& Lwoff, 1928

Order Pilisuctorida Jankowski, 1966

Family Conidophryidae Kirby, 1941

Genus Conidophrys Chatton \& Lwoff, 1934

\section{(a) Conidophrys pilisuctor Chatton \& Lwoff, 1934}

Locality: Guardamar del Segura (Alicante)

Basibiont: On the amphipods J. marmorata Holmes, 1905 and Jassa slatteryi Conlan, 1990.

Description: This species was described by Chatton and Lwoff $[11,12]$, and their characters coincided with the morphological features of the specimens reported in the present study. The tomite, oval, is attached to the host and becomes trophont (Figs. 1, 2, 3, 4, 6), after passing through various morphological states lacrymoid (Figs. 17, 18), spheroid, cucurbitoid (Figs. 13, 14, 15, 

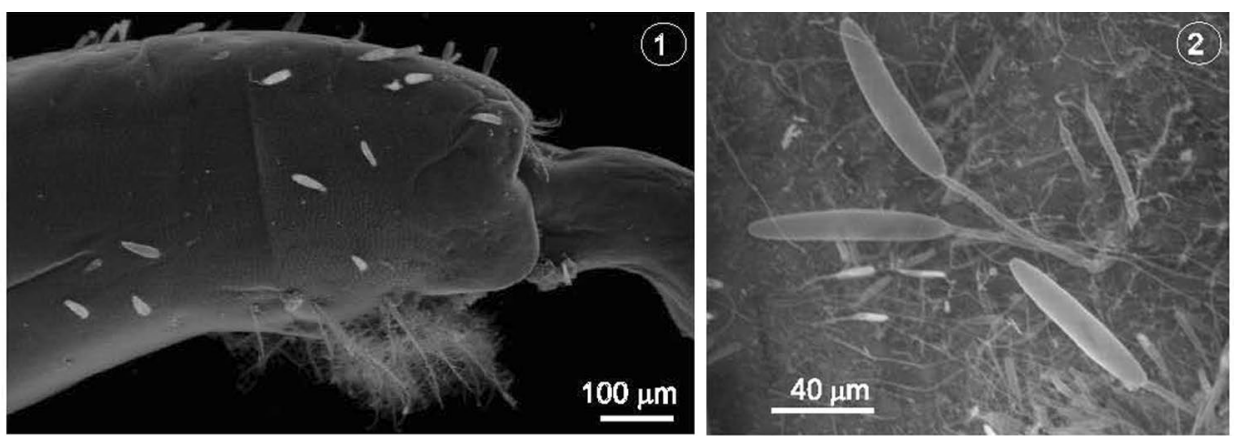

(5)
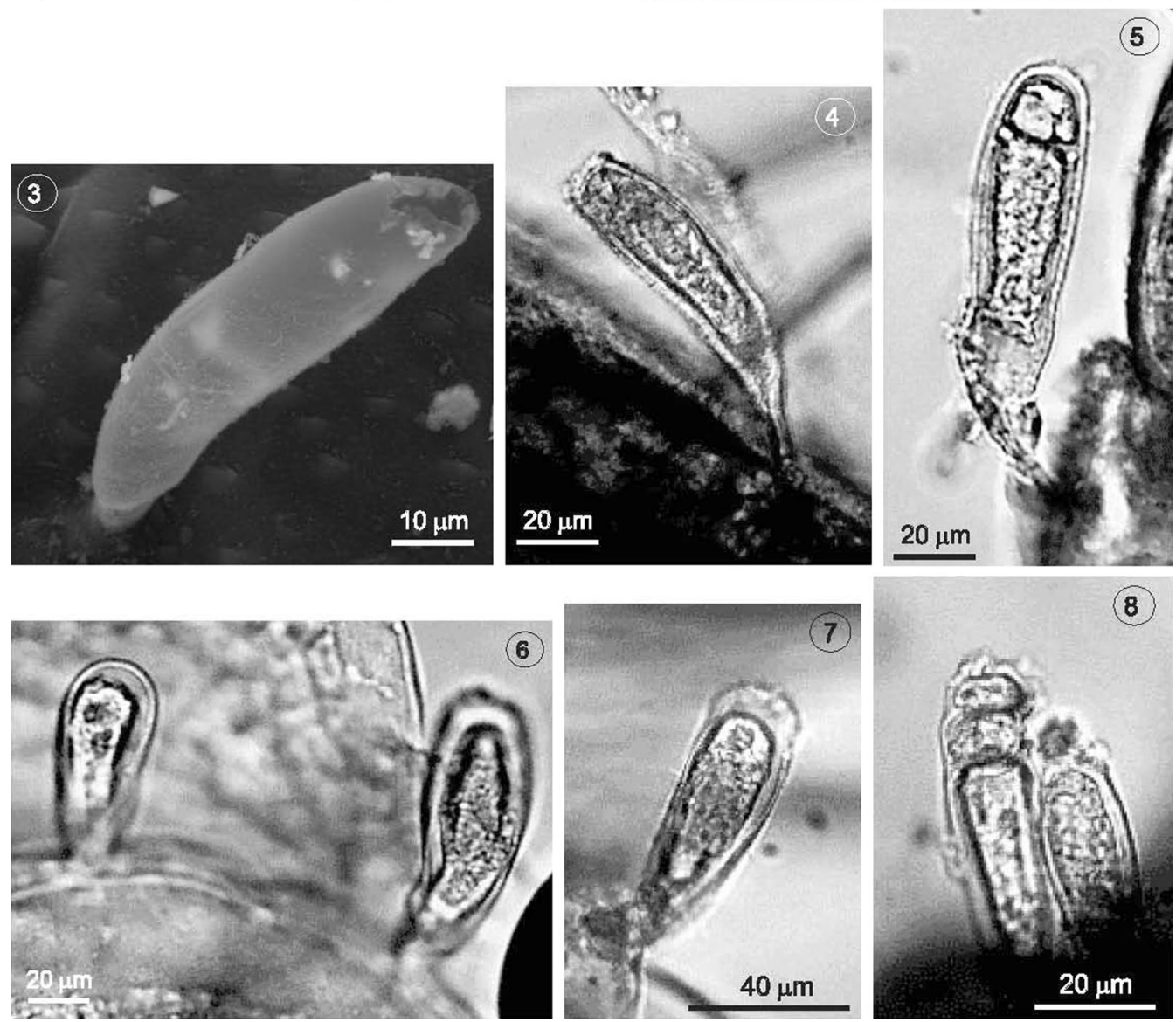

Figs. 1-8 1 Propodus of gnathopod 2 of Jassa slatteryi showing the location of several individuals of Conidophrys pilisuctor. 2 Trophonts of C. pilisuctor attached to setae of the basibiont. $\mathbf{3}$ A trophont of C. pilisuctor with the distal part of the body. $\mathbf{4} \mathrm{A}$ trophont of $C$, pilisuctor showing the macronucleus. 5 A trophotomont of C. pilisuctor with one tomite. $\mathbf{6}$ Trophont of C. pilisuctor developing on the surface of the basibiont. $\mathbf{7}$ A trophont of $C$. pitelkae attached to the surface of the Ericthonius punctatus. 8 A trophotomont of C. pitelkae with two tomites

16). The trophont becomes trophotomont phase where tomites develope (Figs. 5, 8, 9, 10, 11, 12). The tomites are released to the aquatic environment thus becoming the infesting-phase.

Trophonts feed via a multitubular cytostome which is in contact with the host cuticle. The macronucleus was thick and slightly elongated (Fig. 4) with rounded edges. TEM images of C. pilisuctor on the surface of Jassa spp., showed the cytostomal apparatus of this ciliate, which penetrated into the lumen of the cuticle basibiont. The feeding complex was composed by a food chamber surrounding the overall structure. This chamber encircling two groups of structures forming each a cylinder: the outer had microtubular lamellae, and the interior cylinder was the tube feed, the most conspicuous of the cytostomal apparatus, constituted by lamellae, each composed by 

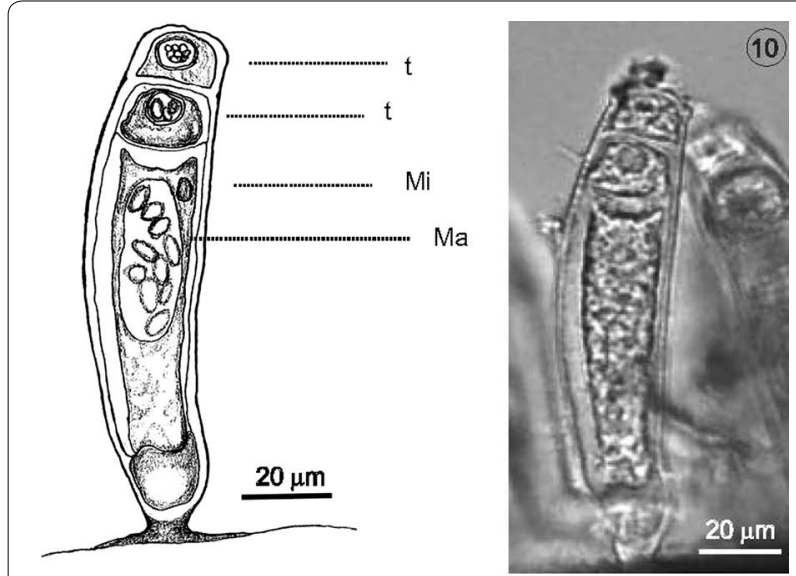

9

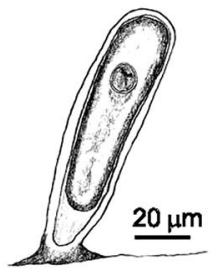

11
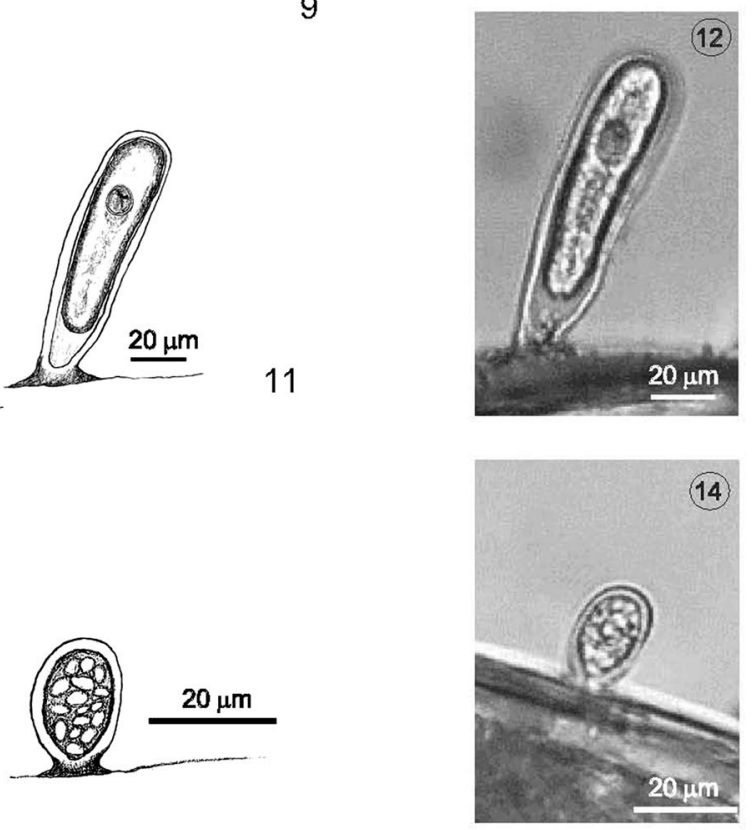

13

Figs. 9-14 9, 10 A trophotomont with two tomites of C. pilisuctor (Ma macronucleus, Mi micronucleus, $t$ tomite). 11, 12 A developing trophont of C. pilisuctor showing the contractile vacuole located centrally. 13, 14 A recently settled trophont of $C$. pilisuctor

several microtubules (Fig. 21a, b). Another TEM photomicrographs were obtained near the most external layer of the amphipod cuticle (Fig. 22a-c) showing cytostomal tubules prolonged from the feeding apparatus adjacent to the lumen of the cuticle. Remarkably, enzymatic activity secreted from the tubules seems to be degrading the surface of the cuticle layer (Fig. 22b, c). In both cases, the presence of the cytostomal apparatus seems to detach the outer layer of the cuticle from the internal layers, leaving a gap among them that might be filled with basibiont hemolymph to feed the ciliates (Figs. 21a, 22a, b).
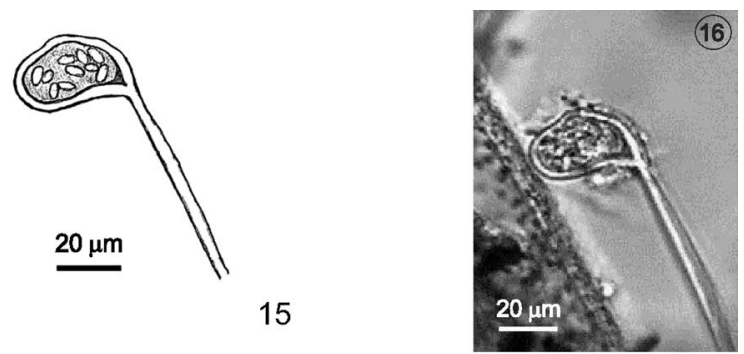

17
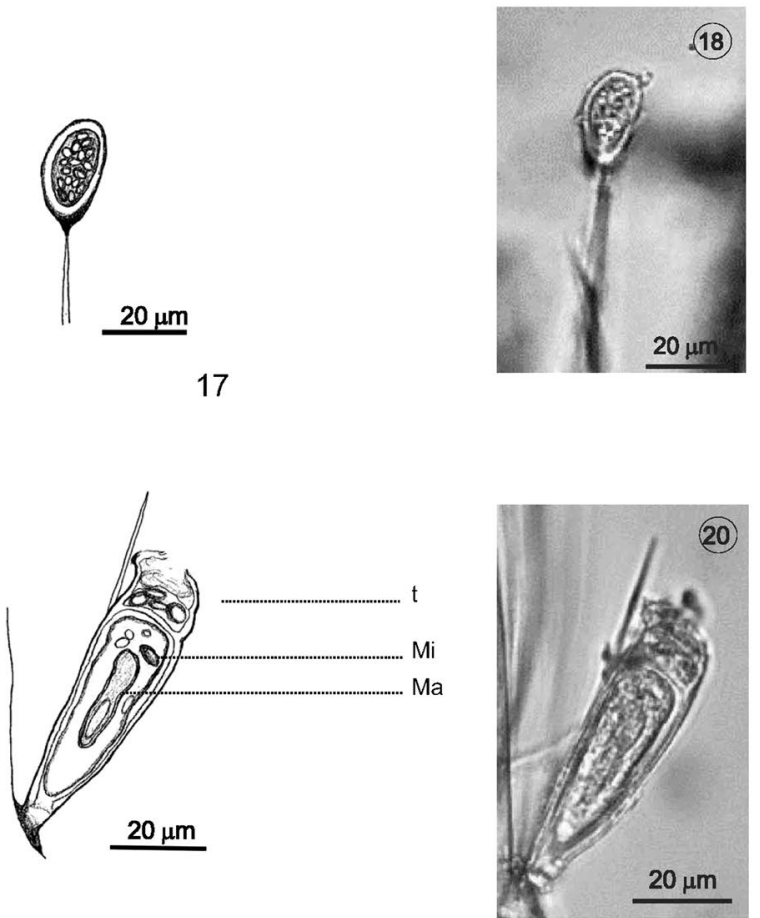

19

Figs. 15-20 15, 16 A cucurbitoid trophont of C. pilisuctor located on the distal part of a seta of the basibiont. 17, 18 A lacrymoid trophont of C. pilisuctor on the tip of a seta. 19, 20 A trophotomont of C. pitelkae with a tomite on the distal end

\section{Taxonomic position}

The species most similar to these suctorian ciliates was C. pilisuctor (=Conidophrys fucatum (Averinzeff, 1916, according to Dovgal and Mayén-Estrada [18]). As this species they had a "trophont subcylindrical elongated enclosed completely by the cyst. Ciliate attached to a short host seta, the seta is wholly covered by the lower thickened part of the cyst. Trophont showed infraciliature with two lateral fields, each with six sublongitudinal kineties. There is a proximal contractile vacuole at the opposite edge of the body attachment area. There is one macronucleus and one micronucleus. Reproduction is by successive linear division 


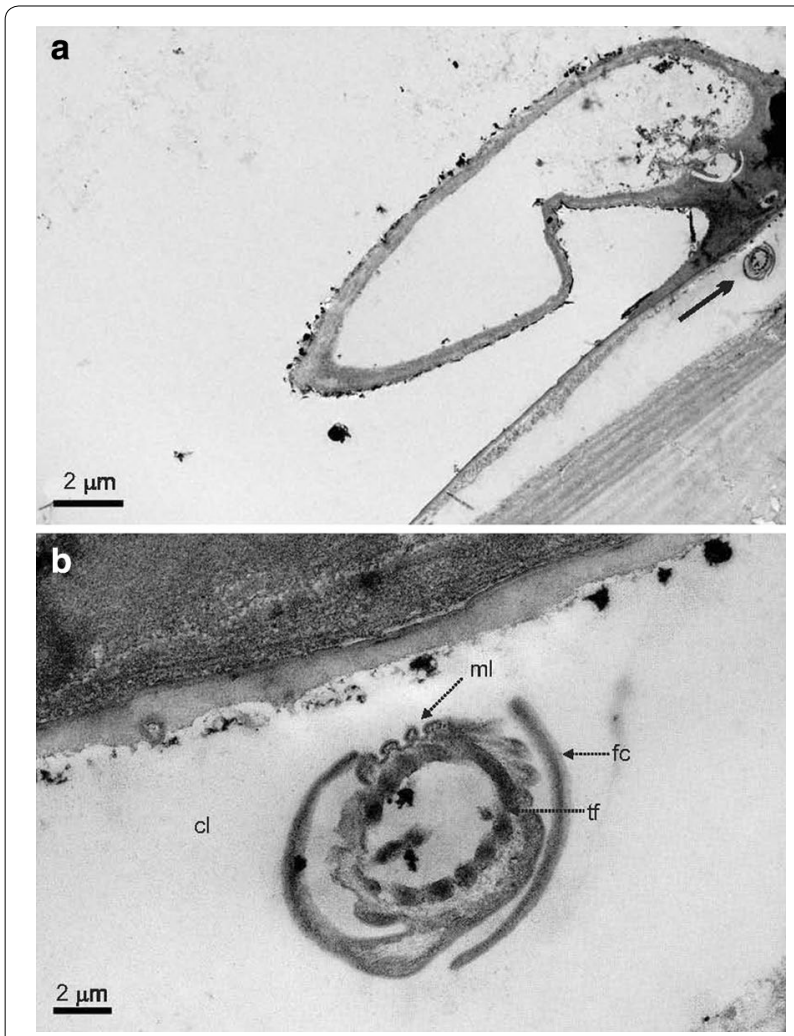

Fig. 21 TEM images of the cytostomal feeding apparatus of $C$. pilisuctor. a Insertion area of the external surface of the amphipod, showing the area in the basibiont cuticle occupied by a transversal section of the ingestive complex (arrow). b Detail of the feeding apparatus showing the food chamber (fc), the microtubular lamellae ( $\mathrm{ml})$, and the tube feed (tf) ( $c$ l cuticle lumen)

(palintomy), producing 1-3 (in rare cases from 5 to 6) swarmers. Discoidal swarmers, with a deep depression at the antapical region. Tomite ciliature with 1-5 kineties placed on the periphery of the body" [16]. The biometrical measures were also analogous to the various descriptions of this species (Table 1). The ciliates showed the key characters of Conidophrys: trophont is elongate and clamped to the secretory setae of the host. The reproduction occurs at the trophont stage by means of the linear palintomic division, and of the species C. pilisuctor: The macronucleus is oviform. Parasite of amphipod crustaceans [16].

Distribution: the epibionts were more frequent on the surface of head, second gnathopod, and in a lesser extent on the second antennae and third and fourth pereiopods. On other appendages this ciliate was present in low proportion (Table 2). Epibionts were located both directly on the surface of the body and on the setae.

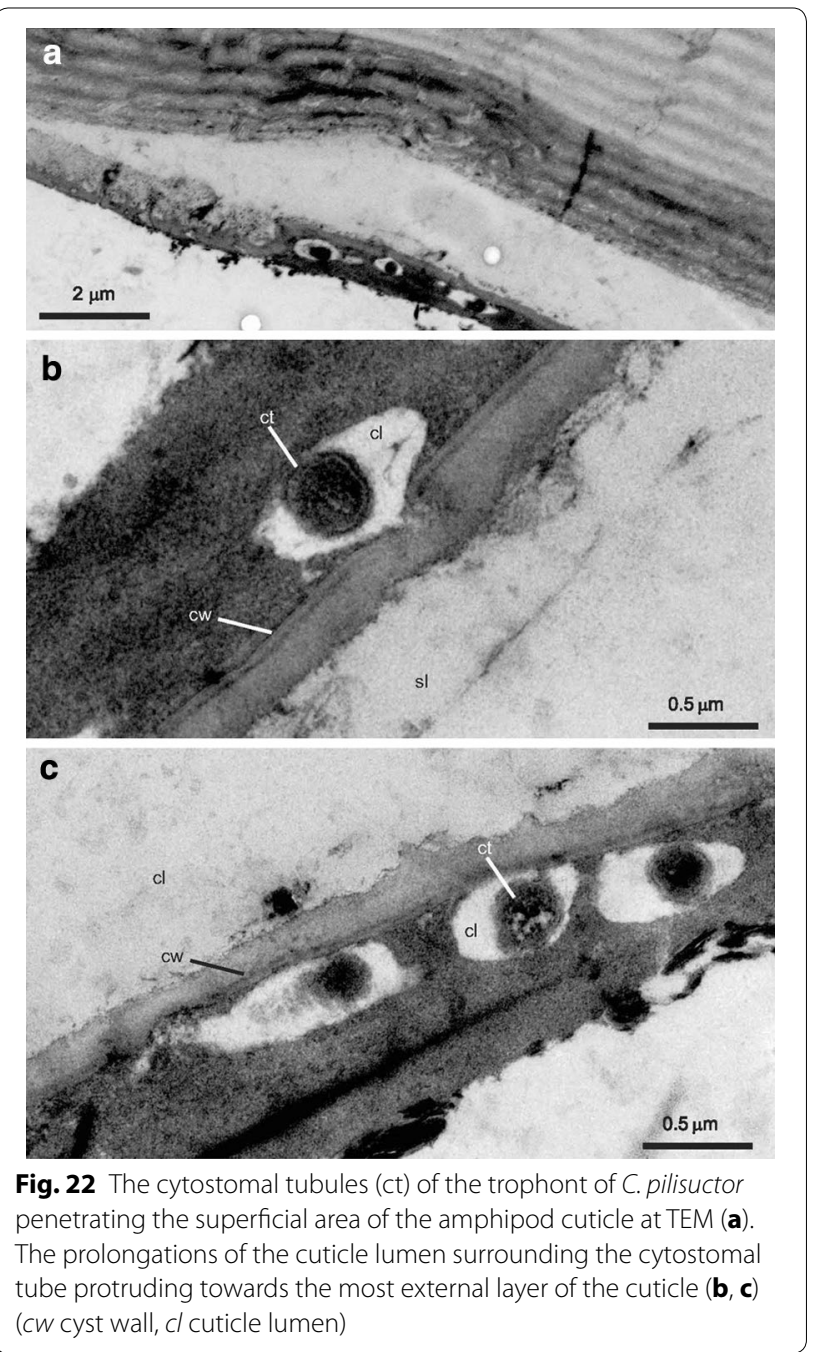

(b) Conidophrys pitelkae Bradbury, 1975

Locality: Guardamar del Segura (Alicante)

Basibiont: Ericthonius punctatus (Bate, 1857)

Description: Ciliates with a life cycle dimorphic and related to the moult cycle of the basibiont crustacean. There was a trophont, long, cylindrical, tapering slightly at the proximal end, covered by a cyst wall (Fig. 7). The cytostome contacted to the surface of the basibiont, the ciliate feeding on the secretions of the setae. The trophont becomes trophotomont (Figs. 8, 19, 20) when reproduced by tomitogenesis forming inside ciliated tomites. The tomites are finally released and may infest basibionts. When the tomite is attached to the host it becomes trophont [7]. The macronucleus was serpentine or band shaped longitudinally crossing the body. 
Table 1 Biometrical measures of the epibiont species in the literature and in the present study

\begin{tabular}{|c|c|c|}
\hline & Length & Width \\
\hline \multicolumn{3}{|l|}{ C. pitelkae (MEAL) } \\
\hline Trophont & $14.6-73.0$ & $7.3-18.5$ \\
\hline Tomont & $31.2-94.2$ & $14.6-25.8$ \\
\hline C. pitelkae (BT) & 65 & \\
\hline \multicolumn{3}{|l|}{ C. pilisuctor (MEAL) } \\
\hline Lacrymoid & $19.6-36.4$ & $8.4-16.8$ \\
\hline Spheroid & $11.2-22.4$ & $8.4-22.4$ \\
\hline Trophont & $22.4-75.6$ & $5.6-22.4$ \\
\hline Trophotomont & $50.4-78.4$ & $16.8-25.2$ \\
\hline Tomite & $5.5-42$ & $8.4-28$ \\
\hline \multicolumn{3}{|l|}{ C. pilisuctor (HR) } \\
\hline Trophont cucurbitoid & $20-60$ & \\
\hline Lacrymoid & $12-15$ & $6-7$ \\
\hline \multicolumn{3}{|l|}{ C. pilisuctor $(\mathrm{CH})$} \\
\hline Trophotomont & $69-84$ & $30-37$ \\
\hline Trophont & $42-63$ & $28-33$ \\
\hline Tomite & $31-41$ & $16-26$ \\
\hline Lacrymoid & $33-42$ & $16-22$ \\
\hline \multicolumn{3}{|c|}{ Conidophrys (Jassa) (present study) } \\
\hline Trophont & $28.5-71.6(62.86)$ & $7.40-19.25(15.94)$ \\
\hline Trophotomont (1 tomite) & 75.9-80.7 (77.26) & $16.6-7.3(16.98)$ \\
\hline Trophotomont (2 tomites) & $87.3-98(90.88)$ & $19.5-3.3(20.8)$ \\
\hline Cucurbitoide & $36.4-43.3(38.46)$ & $13.5-21.6(16.01)$ \\
\hline Spheroid & $18.4-26.6(21.16)$ & $10.5-15(12.41)$ \\
\hline Lacrymoid & $20.83-43.5(25.05)$ & $13.3-21.3(15.26)$ \\
\hline \multicolumn{3}{|c|}{ Conidophrys (Ericthonius) (present study) } \\
\hline Trophont & $53.3-61.6(55.31)$ & $18.3-23.3(19.76)$ \\
\hline Trophotomont (1 tomite) & $63.2-66.6(64.46)$ & $18.6-20(19.76)$ \\
\hline Trophotomont (2 tomites) & $54.3-56.6(55.15)$ & $13.6-15(14.1)$ \\
\hline
\end{tabular}

Mean: numbers in brackets

BT: Bradbury \& Tyson, 1982; MEAL: Mayén-Estrada \& Aladro-Lubel, 1994; HR: Hayward \& Ryland, 1990 (Chatton \& Lwoff, 1935; Fenchel, 1965); CH: Chatterjee et al. 2013

\section{Taxonomic position}

These suctorians were similar to those of $C$. pitelkae. "Trophont is elongate, slender cone shaped, and enclosed in a thin, transparent cyst. Trophont showed two fields of longitudinal unciliated kineties, a right with four and a left with six kineties. The macronucleus is long, serpentine, with conspicuous endosomes, fan-shaped at distal end. There is a micronucleus near the macronucleus. There is single contractile vacuole. Reproduction is by successive linear palintomy forming a single tomite. Tomite is a flattened with dorsal surface curved, with two large ventral depressions, anterior leads to cytostome. Five kineties form a ciliary fringe encircling partly the tomite lateral surface, whereas other five kineties form
Table 2 Minimum and maximum values of number of epibionts (mean) on the different colonised anatomical units

\begin{tabular}{|c|c|c|c|c|}
\hline & \multicolumn{2}{|l|}{ Jassa spp. } & \multicolumn{2}{|c|}{ E. punctatus } \\
\hline & Right & Left & Right & Left \\
\hline Eye & & & & $0-3(0.13)$ \\
\hline 1st antennae & $0-2(0.18)$ & $0-2(0.18)$ & $0-6(0.28)$ & $0-6(0.66)$ \\
\hline 2nd antennae & $0-11(0.63)$ & $0-3(0.25)$ & $0-1(0.13)$ & $0-1(0.31)$ \\
\hline Mandibula & & $0-2(0.05)$ & $0-1(0.05)$ & \\
\hline Gnathopod 1 & $0-1(0.13)$ & $0-2(0.15)$ & $0-1(0.06)$ & $0-3(0.22)$ \\
\hline Gnathopod 2 & $0-13(1.35)$ & $0-4(0.8)$ & $0-1(0.03)$ & $0-2(0.13)$ \\
\hline Pereiopod 3 & $0-5(0.9)$ & $0-8(0.75)$ & $0-1(0.13)$ & $0-2(0.09)$ \\
\hline Pereiopod 4 & $0-5(0.38)$ & $0-11(0.93)$ & $0-1(0.03)$ & $0-2(0.13)$ \\
\hline Pereiopod 5 & $0-2(0.2)$ & $0-3(0.3)$ & $0-1(0.03)$ & $0-5(0.34)$ \\
\hline Pereiopod 6 & $1-5(0.68)$ & $0-10(0.8)$ & $0-1(0.03)$ & $0-1(0.03)$ \\
\hline Pereiopod 7 & $0-5(0.13)$ & $0-8(0.85)$ & $0-1(0.03)$ & $0-2(0.06)$ \\
\hline Pleopods & & & & $0-1(0.03)$ \\
\hline Uropod 1 & $0-1(0.03)$ & $0-3(0.1)$ & & \\
\hline Uropod 2 & $0-2(0.1)$ & $0-1(0.1)$ & & \\
\hline Uropod 3 & $0-4(0.23)$ & $0-4(0.3)$ & & \\
\hline Head & $0-7(1.35)$ & & $0-15(2.13)$ & \\
\hline Pereion & $0-1(0.08)$ & & $0-7(0.41)$ & \\
\hline Pleon & $0-10(0.38)$ & & $0-4(0.19)$ & \\
\hline Urosome & $0-2(0.3)$ & & $0-1(0.13)$ & \\
\hline Telson & $0-1(0.1)$ & & & \\
\hline
\end{tabular}

the ventral ciliature. Macronucleus of tomite is rodshaped and oriented antero-posteriorly" [16]. Biometrical data of the ciliates were similar to those of former description of $C$. pitelkae (Table 1). The key character of this species-a ribbon-like macronucleus with appreciable widening at the upper part of the cell body in tomont stages-was also observed in these ciliates [16].

Distribution: the epibionts were located on the surface of the body, mainly on the head and pereion, and less frequently on the pleon and urosome. It was also frequent on antennae. No epibionts were recorded on appendages (Table 2).

\section{Spatial location of the epibiosis}

The number of epibionts and the prevalence in both basibionts species is shown in Table 3 . The highest values were observed on Jassa spp. The number and distribution of epibionts on the different anatomical units are shown in Table 2.

The relative proportions of the number of epibionts in different areas of the body considering the anterio-posterior axis of the basibiont of both amphipod species is shown in Fig. 2. There was a significant difference in the multiple sample comparison analysis $(\mathrm{p}<0.05, \mathrm{n}=351)$ in the epibiosis prevalence between both amphipod genera. The correlation analysis carried out to test 
Table 3 Number of basibionts with and without epibionts, prevalence (\%) and epibiosis intensity (mean number of Conidophrys per basibiont \pm SE)

\begin{tabular}{llllll}
\hline & $\begin{array}{l}\text { With } \\
\text { epibionts }\end{array}$ & $\begin{array}{l}\text { Without } \\
\text { epibionts }\end{array}$ & Total & $\begin{array}{l}\text { Preva- } \\
\text { lence }\end{array}$ & Intensity \\
\hline $\begin{array}{l}\text { Jassa spp. } \\
\text { (C.pilisuc- }\end{array}$ & 69 & 132 & 201 & 34.33 & $14 \pm 3$ \\
tor) & & 114 & 150 & 24.00 & $6 \pm 1$ \\
$\begin{array}{l}\text { E.punctatus } \\
\text { (C.pitel- }\end{array}$ & 36 & & & & \\
kae) & & & & & \\
\hline
\end{tabular}

differences in the number of epibionts on the anatomical unit colonised between right and left sides of the amphipod indicated that in Jassa spp. all pereiopods and second and third uropods were significantly correlated, thus indicating a similar colonisation in right and left appendages $(\mathrm{p}<0.05, \mathrm{n}=40)$, while in E. punctatus only correlated the fourth pereiopods (Table 2).

\section{Discussion}

Jassa marmorata, J. slatteryi and E. punctatus are tubicolous marine amphipods belonging to Ischyroceridae family, which are widely distributed in fouling communities and hard substrata around the world [3, 36]. This study is the first describing the epibiont presence of apostomid ciliates Conidophrys spp. on these three species.

The most important difference between $C$. pilisuctor and $C$. pitelkae was referred to the stages of the trophont, from the settlement of the tomite on the surface of the basibiont. The epibionts of $C$. pilisuctor, observed on Jassa spp., presented stages of tomont, trophotomont, spheroid, lacrymoid and cucurbitoid. In contrast, the epibionts of C. pitelkae, recorded on E. punctatus, were smaller than those of $C$. pilisuctor and presented stages of tomont and trophotomont, all trophonts showing a similar morphology except for the size of the body.

The measures of C. pilisuctor on Jassa spp. were similar to those indicated by Mayén-Estrada and Aladro-Lubel [32] for Hyalella azteca. The measures of C. pitelkae on E. punctatus were similar to those of [8] for the shrimp Crangon crangon (Table 1).

With regard to the TEM images of the feeding complex of $C$. pilisuctor, there are several descriptions in the literature about this apparatus in apostomatids. In Conidophrys, the sole work was performed in C. pitelkae [8] describing its connection with the setae of the decapod C. crangon. Most of the organisms observed in this study were directly attached to the cuticle of the basibiont rather to their setae, and thus precludes direct comparison of their feeding complex. Analogies between both species are the tubules that constitute the cytostome running parallel to the surface of the cuticle, which provide the contact between epibiont and basibiont by fusion with the cuticle (Fig. 22b). Some of these tubules also pass through the cuticle into the lumen created between the cuticle layers of the basibiont. The ciliate structure found within the lumen of the amphipod (Fig. 21b) resembles the food tube described for Ascophrys sp. [9], but we did not find an extensive digestion of the cuticle of the basibiont as observed in the cuticle of Palaemon serratus. Comparatively, the feeding complex of $C$. pilisuctor was less complex and more superficial than those of C. pitelkae and Ascophrys sp. The images of the present study represent the first data about the feeding apparatus of $C$. pilisuctor.

Conidophrys species have been reported on different crustacean groups, with amphipods and isopods representing the highest proportion of basibiont species (Table 4). Bradbury [7] described the species C. pitelkae indicating its settlement on cuticle hairs of their basibiont, the decapod C. crangon. This author did not show the spatial distribution of the epibiont on the body of the basibiont. C. pitelkae was also found on several crustacean species at mangrove areas of Malaysia [24]. In these areas, $C$. pitelkae was mainly found on the anterior part of the mysidacean Mesopodopsis orientalis, together to other epibiont species. In contrast, in decapods of the genus Acetes, the presence of other epibionts in high abundances such as Lagenophrys and Acineta make that C. pitelkae colonised mainly the posterior part of the basibiont. However, Mayén-Estrada and Aladro-Lubel [31] found this epibiont located mainly on the pereiopods, and also on pleopods of the decapod Penaeus setiferus. In the present study C. piltelkae was observed on anterior areas of E. punctatus (Fig. 23).

Conidophrys pilisuctor has been reported on isopods and amphipods. On the freshwater amphipod Hialella azteca, C. pilisuctor was found on pereiopods and antennae [32]. Equally, on the isopod Idothea baltica and the amphipods Gammarus locusta and G. oceanicus, it was recorded on the setae of pereiopods [19]. On the isopod Jaera albifrons on antennae, antennulae and pereiopods [30]. On the isopod Limnoria lignorum and the amphipod Monocorophium acherusicum, it was found on "secretory hairs" of the cuticle [33]. Finally, it was mainly reported on gnathopods, pereiopods, and less abundantly on pleopods and uropods of the amphipod Melita petronioi $[10]$.

From these studies, the distribution of Conidophrys on the different basibiont species varied significantly, although it seems that there was a preference for the setae of the cuticle, and the appendages of the anterior half of the body. In our study the epibionts were mainly present directly on the cuticle of the amphipod and to a 
Table 4 Conidophrys species and their basibionts: isopod (I), amphipod (A), decapod (D), misidacean (M)

\begin{tabular}{|c|c|c|c|}
\hline Species & Basibionts & Locality & References \\
\hline \multirow[t]{11}{*}{ Conidophrys pilisuctor } & Jaera ischiosetosa (I) & South Wales, UK & {$[30]$} \\
\hline & $\begin{array}{l}\text { Ilyarachna bergendali (I), I. hirticeps (I), I. torleivi (I), and } \\
\text { Tytthocope megalura (I) }\end{array}$ & Icelandic waters & {$[34]$} \\
\hline & Idothea baltica (I) & $\begin{array}{l}\text { Øresund (between Denmark and Sweden) and from } \\
\text { Isefjord (Northern Sealand, Denmark) }\end{array}$ & [19] \\
\hline & Limnoria lignorum (I) & California, USA & [33] \\
\hline & Hyalella azteca (A) & Pátzcuaro Lake (Michoacán Mexico) & [32] \\
\hline & Monocorophium acherusicum (A), Hyale perieri & Black Sea & {$[6,17]$} \\
\hline & M. acherusicum (A) & Mediterranean Sea near Set (France) & {$[11]$} \\
\hline & Gammarus locusta (A), G. oceanicus (A) & $\begin{array}{l}\text { Øresund (between Denmark and Sweden) and from } \\
\text { Isefjord (Northern Sealand, Denmark) }\end{array}$ & {$[19]$} \\
\hline & M. acherusicum (A) & California, USA & [33] \\
\hline & $\begin{array}{l}\text { M. acherusicum (A), Ericthonius difformis (A), Micro- } \\
\text { deutopus gryllotalpa (A), Jassa falcata (A), J. dentex } \\
\text { (A), Gammarus locusta (A), Dexamine spinosa (A) }\end{array}$ & Roscoff, France & {$[11,12]$} \\
\hline & Melita petronioi (A) & $\begin{array}{l}\text { Pombas Island, inside the Patos Lagoon, Rio Grande } \\
\text { do Sulstate (Brazil) }\end{array}$ & {$[10]$} \\
\hline \multirow[t]{3}{*}{ Conidophrys pitelkae } & Crangon crangon (D) & Atlantic coast of France & [7] \\
\hline & Penaeus setiferus (D) & Tamiahua lagoon (Atlantic coast of Mexico) & {$[31]$} \\
\hline & $\begin{array}{l}\text { Mesopodopsis orientalis (M), Acetes japonicus (D), } \\
\text { A. sibogae (D), A. indicus (D), Fenneropenaeus } \\
\text { merguiensis (D) }\end{array}$ & Mangrove areas of Malaysia & {$[24]$} \\
\hline Conidophrys fucatum & Gammarus balcanicus (A) & Freshwater areas Ukraine & [16] \\
\hline \multirow[t]{2}{*}{ Conidophrys guttipotor } & Sphaeroma serratum (I) & France & [12] \\
\hline & Jaera ischiosetosa (I) & South Wales, UK & {$[30]$} \\
\hline \multirow[t]{3}{*}{ Conidophrys enkyostotrophos } & Gammarus oceanicus (A) & Barents Sea & [28] \\
\hline & $\begin{array}{l}\text { G. subtipicus (A) } \\
\text { G. aequicauda (A) }\end{array}$ & Sivash Gulf of the Sea of Asov & {$[15]$} \\
\hline & G. olivii (A) & $\begin{array}{l}\text { Kamysh-Burun } \\
\text { Bay, Black Sea }\end{array}$ & {$[16]$} \\
\hline
\end{tabular}
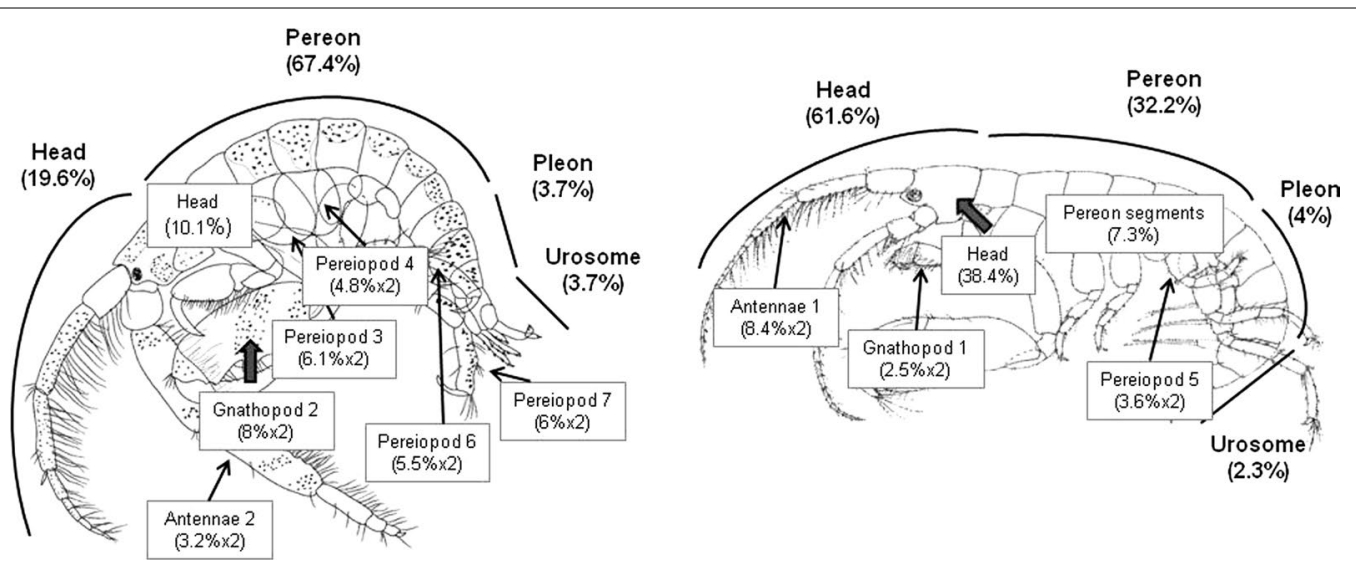

Fig. 23 Relative proportions of the number of epibionts located in the anatomical units colonised in Jassa spp. and Ericthonius punctatus, grouped following the anterior posterior axis of the basibiont. The groups contained, from the anterior to the posterior end of the amphipod: (1) head, eyes; (2) antennae 1 and 2; (3) gnathopods, pereiopods and pereion; (4) pleopods, pleon; (5) uropods, urosome, telson 
lesser extent on the setae of their pereiopods. However, there are some findings when the host setae were short that created the illusion of a direct attachment to the hosts' cuticle. For example according to [11] the attachment to the short setae observed in C. pilisuctor in particular from the amphipod crustacean Jassa falcata. The three studied amphipods, J. marmorata, J. slatteryi and E. punctatus produce 'amphipod silk', through specialized glands in the third and fourth pereiopods, and build tubes cemented with fine suspended matter where they live [4]. Inside them, they protrude water movements to filter organic matter and gather detritus [14] that may be related to the greater probability of becoming colonised on the anterior part. Thus, the production of amphipod silk could be also related to the higher colonisation of the third and fourth pereiopods. Moreover, this rich environment of external nutrients may be responsible to the higher distribution of the epibionts directly on the cuticula than on the setae of the amphipods [8].

Conidophrys has its entire life-cycle on the crustacean basibiont. There is a synchronization between the lifecycles of epibiont and basibiont, where the premoult events of the crustacean determine the tomitogenesis in Conidophrys trophont, so that the tomites are released in the water environment when moulting occurs. Tomites can colonise new surfaces, including the new cuticle of the basibiont [7]. The epibiont contacts with the basibiont by means of the cytostome, and exudate secretions from the basibiont cuticle-i.e. hemolymph-are incorporated through the cytostome into the cytoplasm of the ciliate. Therefore, the impact of the epibiont on the external surface of the crustacean, from the feeding point of view, depends on the abundance of trophont stages on the cuticle of the basibiont.

The prevalence on Jassa spp. was $34.33 \%$ and on $E$. punctatus $24 \%$. In $H$. azteca, these percentages for $C$. pilisuctor fluctuated between 23.4 and $55.2 \%$ [32]. On that study the high values of number of epibionts were recorded on the pereiopods and the antennae, while in the individuals of Jassa spp. the highest numbers of epibionts were observed on the head, second gnathopods, and third and fourth pereiopods. Regarding C. pitelkae, the highest percentages of this ciliate on Penaeus setiferus were observed on the pereiopods and pleopods [31], while on E. punctatus, the epibionts were more abundant on the surface of the head and pereion. This fact may indicate that the preference of epibionts for certain body parts might vary according to the crustacean basibiont species, their biological activities and the characteristics of their cuticle. The fact that all amphipods studied herein are tube-building could facilitate the settlement of tomites, preventing them from being dragged by the currents.
Epibiosis does not imply to fill certain requirements for the participants, except for attachment to a substrate. There could be indeed a number of effects on both the epibiont and the basibiont, and the relation could be considered from symbiosis to commensalism and parasitism. The epibiosis might produce evolutive changes in the participants in the long term [1,29]. The effects can be advantages for the epibiont in dispersal and geographical expansion, increasing the supply of nutrients and protection against predation or negative condition of the environment [20]. Epibiosis can be disadvantageous for the epibiont by causing ontogenetic or behavioural changes on the basibiont [2]. Epibiosis can be beneficial for the basibiont by providing both mimetic protection and cleaning $[18,25]$. On the contrary, epibiosis may be negative for the basibiont by restricting mobility and affect growth, moulting and functionality of several organs (eyes, gills and appendages), causing an increase in predation hazard. Epibiont and basibiont might compete for nutrients [22]. In the case of the epibiosis of the present study, several areas of the basibiont, such as the head and anterior appendages (gnathopods and pereiopods), showed a relatively high number of epibionts, and this fact could have negative effects on the sensorial activity of the crustacean. In addition, the epibionts on the surface of the appendages may restrict the ability of movement.

Also, certain tube-building amphipod species such as Crassicorophium bonellii and Lembos websteri ingest tube-wall material during poor feeding conditions, especially around the tube entrances [37]. This fact might negatively affect the epibiont populations, since epibionts were not protect and may be eliminated due the grooming and cleaning or other antifouling activities of the amphipod. In the other sense, the contribution of tubicolous amphipods to biofouling is important, and they achieve improved natural dispersal ability, being this fact reflected on the present epibiontic species [37].

The high densities of the two Jassa species and E. punctatus associated to the fish farm fouling (Fernandez-Gonzalez, pers. obs) may increase the release of tomites to the marine environment and also ensure the availability? of basibiont individuals around them. Moreover, the water around the fish farm is extremely rich in organic substances [13] that can favour the development of the ciliates. This leads to raise the following hypotheses: (1) that freeliving amphipods-planktonic or benthic not tube-building-would be less susceptible to this type of epibiosis, (2) tube amphipods of control areas-with a lower input of organic substances-would have less ciliates than those close to the fish farm. Overall, this study reveals the presence of two apostomatid ciliate epibionts in three tubebuilding amphipods around fish farms and their spatial 
distribution around the body of the basibionts. More studies need to be done to address the former hypotheses in order to know if the rich-nutrient environment around the fish farms might benefit the ciliate epibiosis.

\section{Authors' contribution}

GFL participated in the samples observation, epibiont identification. VFG participated in sampling, identification of basibionts, and measurement of paremeters involved in the epibiosis. PSJ participated in sampling. AR participate in obtention of SEM images of the epibiont and schemes of the organisms. All authors contributed in drafted the manuscript. All authors read and approved the final manuscript.

\section{Author details}

${ }^{1}$ Department of Zoology, Complutense University, Madrid, Spain. ${ }^{2}$ Department of Marine Sciences and Applied Biology, University of Alicante, Alicante, Spain. ${ }^{3}$ Department of Ecology, Environment and Evolution, La Trobe University, Melbourne, Australia.

\section{Acknowledgements}

The authors thank Inés Pazos and Jesús Méndez (CACTI, University of Vigo) (IIM, Vigo) for their technical support preparing the samples for electron microscopy. We are indebted to Santiago Pascual (IIM, CSIC) for supporting the electron microscopy carried in this study. AR is supported by a "Fundación Barrié de la Maza" postdoctoral fellowship and a Securing Food, Water and the Environment Research Focus Area grant (La Trobe University).

\section{Competing interests}

The authors declare that they have no competing interests.

Received: 10 November 2015 Accepted: 11 March 2016

Published online: 01 December 2016

\section{References}

1. Abelló P, Villanueva R, Gili JM. Epibiosis in deepsea crab populations as indicator of biological and behavioural characteristics of the host. J Mar Biol Assoc UK. 1990;70:687-95.

2. Becker K, Wahl M. Behaviour patterns as natural antifouling mechanisms of tropical marine crabs. J Exp Mar Biol Ecol. 1996;203:245-58.

3. Beermann J. Ecological differentiation among amphipod species in marine fouling communities: studies on sympatric species of the genus Jassa Leach, 1814 (Crustacea, Amphipoda). Ph.D. thesis, Free Univ. of Berlin; 2013.

4. Beermann J. Spatial and seasonal population dynamics of sympatric Jassa species (Crustacea, Amphipoda). J Exp Mar Biol Ecol. 2014;459:8-16.

5. Bergey EA, Resh VH. Effects of burrowing by a stream caddisfly on caseassociated algae. J N Am Benthol Soc. 1994;13:379-90.

6. Boshko EG, Dovgal IV. The first record of pilisuctorid ciliates (Ciliophora, Pilisuctorida) in the Black Sea. Vestn Zool. 2000;34:112.

7. Bradbury PC. Conidophrys pitelkae, a new species of pilisuctorian from cuticular hairs of Crangon crangon (Linneus). Acta Protozool. 1975;14:161-70.

8. Bradbury PC, Tyson G. The fine structure of Conidophrys pitelkae Bradbury related to its life cycle and taxonomic position in the Apostomatida. J Protozool. 1982;29:184-94.

9. Bradbury P, Deroux G, Campillo A. The feeding apparatus of a chitinivorous ciliate. Tissue Cell. 1987;19:351-63.

10. Chatterjee T, Fernandez-Leborans G, Senna A. Ciliate epibionts on Melita petronioi Senna et al., 2012 (Crustacea: Amphipoda) from Brazil. Cah Biol Mar. 2013;54:393-404.

11. Chatton E, Lwoff A. Sur un infusoire parasite des poils sécréteurs des Crustacés Edriophtalmes et la famille nouvelle des Pilisuctoridae. Comp Rend Acad Sci. 1934;199:696-9.

12. Chatton E, Lwoff A. Les Pilisuctoridæ Ch. et Lw. Ciliés parasites des poils sécréteurs des Crustacés Edriophthalmes. Polarité, orientation et desmodexie chez les infusoires. Bull Biol France Belg. 1936;70:86-144.

13. Cook EJ, Black KD, Sayer MDJ, Cromey CJ, Angel D, Spanier E, Tseme A, Katz T, Eden N, Karakassis I, Tsapakis M, Apostolaki E, Malej A. The influence of caged mariculture on the early development of sublittoral fouling communities: a pan-European study. ICES J Mar Sci. 2006;63:637-49.

14. Dixon IMT, Moore PG. A comparative study on the tubes and feeding behaviour of eight species of corophioid Amphipoda and their bearing on phylogenetic relationships within the Corophioidea. Philos Trans R Soc Lond B. 1997;352:93-112.

15. Dovgal IV. Conidophrys enkystotrophos (Ciliophora, Pilisuctorida) a new for Ukrainian fauna species of parasitic ciliates. Vestn Zool. 2003;37:40.

16. Dovgal IV, Boshko EV. Second find of a Pilisuctorid ciliate (Apostomatia, Pilisuctorida) on a freshwater gammarid amphipode. Vestn Zool. 2007;41:510.

17. Dovgal IV, Boshko EV, Krakhmalnyy AF, Kluchnik NN. Pilisuctorians (Ciliophora, Apostomatia, Pilisuctorida)—a new group of parasitic ciliates in Ukrainian fauna. Vestn Zool. 2005;19(Supplement):110-1.

18. Dovgal IV, Mayén-Estrada R. A taxonomic revision of order Pilisuctorida (Ciliophora, Apostomatia) with keys to the subordinate taxa. Zootaxa. 2015:4040:543-58.

19. Feifarek BP. Spines and epibionts as antipredator defense in the thorny oyster Spondylus americanus Herman. J Exp Mar Biol Ecol. 1987;105:39-56.

20. Fenchel T. On the ciliate fauna associated with the marine species of the amphipod genus Gammarus J.G. Fabricius. Ophelia. 1965;2:281-303.

21. Fernandez-Leborans $G$. A review of recently described epibioses of ciliate protozoa on Crustacea. Crustaceana. 2009;82:167-89.

22. Fernandez-Leborans G, Castro de Zaldumbide M. The morphology of Anophrys arenicola sp. nov. (Ciliophora, Scuticociliatida). J Nat Hist. 1986;20:71-106.

23. Fernandez-Leborans G, Gabilondo R. Taxonomy and distribution of the hydrozoan and protozoan epibionts on Pagurus bernhardus (Linnaeus, 1758) (Crustacea, Decapoda) from Scotland. Acta Zool. 2006;87:33-48.

24. Fernandez-Leborans G, Hanamura Y, Siow R, Chee P-E. Intersite epibiosis characterization on dominant mangrove crustaceans in Malaysia. Contrib Zool. 2009;78:9-23.

25. Fishlyn DA, Phillips DW. Chemical camouflaging and behavioral defense against a predatory seastar by three species of gastropods from the surf grass Phyllospadix community. Biol Bull. 1980;158:34-48.

26. Gregori M, Fernández-Leborans G, Roura A, González AF, Pascual S. Description of a new epibiotic relationship (Suctorian-Copepoda) in NE Atlantic waters: from morphological to phylogenetic analyses. Acta Zool. 2015. doi:10.1111/azo.12113.

27. Hayward PJ, Ryland JS. The marine fauna of the British Isles and NorthWest Europe: 1. Introduction and protozoans to arthropods. Oxford: Clarendon Press; 1990.

28. Jankowski A. Morphology and development cycle of Conidophrys enkystotrophos sp. nov. in connection with phylogenetic and systematic problems of the family Conidophryidae Guilcher 1951. In: Mat IV Konf Mold Zool; 1966. p. 123-9.

29. Jeffries WB, Voris HK, Poovachiranon S. Age of the mangrove crab Scylla serrata at colonization by stalked barnacles of the genus Octolasmis. Biol Bull. 1992;182:188-94.

30. Jones MB, Khan MA. The ocurrence of Conidophrys species (Protozoa, Ciliata) on members of the Jaera albifrons Leach group. Acta Protozool. 1970;8:149-53.

31. Mayén-Estrada R, Aladro-Lubel MA. Primer registro de Conidophrys pitelkae (Ciliophora, Apostomatia, Pilisuctorida) en crustáceos decápodos de la laguna de Tamiahua, Veracruz. Anales Inst Biol Univ Nac Autón México Zool. 1994;65:1-10.

32. Mayén-Estrada R, Aladro-Lubel MA. First record of Conidophrys pilisuctor (Ciliophora: Pilisuctorida) as ectosymbiont of Hyalella azteca from Mexico. Hydrobiologia. 2004;529:19-26.

33. Mohr JL, Leveque JA. Occurrence of Conidophrys pilisuctor on Corophium acherusicum in Californian waters. J Parasitol. 1948;34:253.

34. Ólafsdóttir SH, Svavarsson J. Ciliate (Protozoa) epibionts of deep-water asellote isopods (Crustacea): pattern and diversity. J Crustac Biol. 2002;22:607-18.

35. Oliverio M, Gerosa G, Cocco M. First record of Pinctada radiata (Bivalvia, Pteriidae) epibiont on the loggerhead sea turtle Caretta caretta (Chelonia, Cheloniidae). Boll Malacol. 1992;28:149-52.

36. Ruffo S. Handbook of the The Amphipoda of the Mediterranean. Memoires del'Institute Oceanographique. Fondation Albert 1er, Prince de Monaco, vol. 13; 1982-1998. 
37. Shillaker RO, Moore PG. The biology of brooding in the amphipods Lembos websteri Bate and Corophium bonnellii Milne Edwards. J Exp Mar Biol Ecol. 1987;110:113-32.

38. Threlkeld ST, Chiavelli DA, Willey RL. The organization of zooplankton epibiont communities. Trends Ecol Evol. 1993;8:317-21.

39. Utz LR. Identification, life history, and ecology of peritrich ciliates as epibionts on calanoid copepods in the Chesapeake Bay. Ph.D, Univ. Maryland; 2003.
40. Wahl M. Ecological lever and interface ecology: epibiosis modulates the interaction between host and environment. Biofouling. 2008;24:427-38.

41. Wahl M, Hay ME, Eenderlein P. Effects of epibiosis on consumer-prey interactions. Hydrobiologia. 1997;355:49-59.

\section{Submit your next manuscript to BioMed Central and we will help you at every step:}

- We accept pre-submission inquiries

- Our selector tool helps you to find the most relevant journal

- We provide round the clock customer support

- Convenient online submission

- Thorough peer review

- Inclusion in PubMed and all major indexing services

- Maximum visibility for your research

Submit your manuscript at

www.biomedcentral com/submit 